\title{
Occurrence of IgM antibodies against BK and JC polyomaviruses during pregnancy
}

\author{
PATRICIA E GIBSON, ANNE M FIELD, SYLVIA D GARDNER, \\ DULCIE V COLEMAN*
}

From the Virus Reference Laboratory, Central Public Health Laboratory, Colindale Avenue, London
and the *Department of Experimental Pathology, St Mary's Hospital Medical School, London

SUMMARY In a serological survey of 430 pregnant women 45 had high or rising titres of BK-virus haemagglutination-inhibiting antibodies. The presence of BK-virus-specific IgM was confirmed in 10 $\omega_{\oplus}$ of these women. No BK-virus-specific IgM was detected in the samples of cord blood from the babies: born to these women. The sera from 40 women known to be excreting inclusion-bearing cells during pregnancy were tested for the presence of BK-virus- and JC-virus-specific IgM and IgG. The presence ${ }_{\circ}^{+}$ of BK-virus-specific IgM was confirmed in three cases and JC-virus-specific IgM in seven cases. Specific IgM persisted for several months in some pregnant women. No BK-virus-specific IgM wasc detected in any of the samples of cord blood from the babies born to these women with evidence of polyomavirus infection. No JC-virus-specific IgM was detected in 36 out of 37 of the cord bloods; $\vec{\odot}$ however, in one it is possible that minute amounts of JC-virus-specific IgM were present.

Since the discovery of the human BK and JC polyomaviruses in human tissue, ${ }^{2}$ their widespread distribution has been well documented. ${ }^{3-10}$ Primary infection occurs in childhood, but the mode of transmission and clinical picture are still not known. The viruses are thought to persist in the body after infection. Reactivation of both viruses has been shown to occur in people whose immunity has been impaired for some reason ${ }^{11-16}$ and at this time virus is frequently excreted in the urine. Transplacental transmission has already been shown to occur for two animal polyomaviruses: mouse polyoma ${ }^{17}$ and stump-tailed macaque viruses. ${ }^{18}$

Because there is evidence that during pregnancy immunity is depressed, ${ }^{19}$ the recent survey by Coleman and her colleagues was undertaken. ${ }^{20}$ In this study more than 1000 women were followed during pregnancy and $40(3 \%)$ were found to be excreting a polyomavirus. Evidence was presented to show that the infections were the result of a reactivation of latent virus and were not primary. In the majority of the 40 , reactivation was more likely to be due to JC-virus than BK-virus although the latter also occurred. Serological results indicated that reactivation of $\mathrm{JC}$ or BK viruses had occurred in $20 \%$ of the pregnant women, but no evidence was found to suggest transmission of BK-virus to the fetus. The

Accepted for publication 16 October 1980 cord bloods of 309 newborn babies were examined for BK-virus-specific IgM and all were negative.

This prospective study has provided an abundanto source of material for further investigations and in this report we present additional information on theo, occurrence and persistence of BK- and JC-virusspecific immunoglobulin $\mathbf{M}$ (IgM) in sera obtained from the pregnant women who showed evidence of polyomavirus reactivation and in cord or neonatang blood samples from their babies. The persistence of BK-virus-specific IgM for several months in patients immunosuppressed after renal transplantation has already been demonstrated. ${ }^{14}$ Jung and his colleagues $\$$ showed that high titres of haemagglutination-o inhibiting (HI) antibodies specific for BK-virus persisted for periods up to 20 months and that specific IgM could be detected during this time.

\section{Patients and methods}

SUBJECTS

The group under study in the survey of human polyomavirus in pregnancy by Coleman and colleagues $^{20}$ consisted of 1235 pregnant women@ Nearly half registered at the antenatal clinic during the first trimester of pregnancy and the others $a \bar{E}$ later stages of gestation. At least two maternal serung samples and the cord or neonatal blood samples were collected from each woman and her baby. 674 
The presence of antibody to BK-virus and JC-virus was investigated in sera from 430 of these women. The sera from those with high or rising titres to BK-virus and the cord bloods of their infants were tested for BK-virus-specific IgM. In $\mathbf{4 0}$ of the $\mathbf{1 2 3 5}$ women, inclusion-bearing cells were found in their urine. Sera from these women and cord blood from their infants were examined for the presence of BK-virus- and JC-virus- specific IgM.

\section{HAEMAGGLUTINATION INHIBITION}

Maternal and cord blood samples were tested by $\mathrm{HI}$ for BK-virus and JC-virus antibody. The technique and preparation of antigens has been reported elsewhere. ${ }^{120}$

\section{IMMUNOFLUORESCENCE}

Sera were investigated at dilutions $1 / 2$ and $1 / 10$ for the presence of BK-virus-specific IgM by an immunofluorescence antibody test (FA) which has also been previously described. ${ }^{20}$

\section{LATEX AGGLUTINATION}

A latex agglutination test for rheumatoid factor was performed to exclude any false-positive IgM reactions.

SUCROSE DENSITY GRADIENT FRACTIONATION At least one serum sample from each mother which showed specific IgM immunofluorescent staining for BK-virus was fractionated on a linear sucrose density gradient $(12.5 \%-37.5 \%$ sucrose in complement fixation test (CFT) diluent (Oxoid Ltd)). $\mathbf{0 \cdot 1} \mathrm{ml}$ of each serum was treated with $0.4 \mathrm{ml}$ receptor destroying enzyme (RDE) (Wellcome Reagents Ltd) for 18 hours at $37^{\circ} \mathrm{C}$, inactivated at $52^{\circ} \mathrm{C}$ for 30 minutes, and placed on a $5 \mathrm{ml}$ gradient. The gradients were centrifuged for $17 \frac{1}{2}$ hours at $35000 \mathrm{rpm}$ in an SW-50 rotor on a Beckman L2-50 centrifuge. Ten $0.5 \mathrm{ml}$ fractions were collected from each gradient and examined by $\mathrm{HI}$ for BK-virus-specific IgG and IgM. Separation of the fractions was confirmed by gel immunodiffusion using sheep anti-human $\operatorname{IgA}$, IgG and IgM sera (Wellcome Reagents Ltd).

Because of technical difficulties we were unable to test for JC-virus-specific IgM using the immunofluorescence method. However, at least one serum sample from the $\mathbf{4 0}$ women known to be excreting inclusionbearing cells was fractionated on sucrose density gradients and the resulting fractions tested by $\mathrm{HI}$ for JC-virus-specific IgG and IgM. Cord sera from 37 of the $\mathbf{4 0}$ babies in this group were also fractionated by sucrose density gradients and the fractions examined for BK-virus- and JC-virus-specific IgG and IgM antibodies as described.
IMMUNE ELECTRON MICROSCOPY

Serum fractions containing BK-virus- or JC-virusspecific IgM were further tested by immune electron microscopy (IEM). $0.1 \mathrm{ml}$ serum fraction from the sucrose density gradient was mixed with $0.2 \mathrm{ml} \mathrm{BK}$ virus or JC-virus antigens. These were prepared by either sonicating tissue culture media harvested from infected cell cultures or by sonicating infected cells which had been frozen and thawed three or four times. The antigens were diluted to give about 50 virus particles per grid square in the final preparation. The antigen-antibody mixtures were incubated for 1 hour at room temperature, diluted with $2 \cdot 2 \mathrm{ml}$ of phosphate-buffered saline and centrifuged at 12000 rpm for one hour (in the RC2-B Sorvall centrifuge with a SS-34 rotor). Pellets were resuspended in a drop of distilled water containing $0.025 \%$ bovine plasma albumin and mixed with an equal volume of $3 \%$ phosphotungstic acid $\mathrm{pH}$ 6.5. The mixture was applied to a formvar-carbon-coated grid and the excess blotted off. Representative areas of grids were examined and the total number of virus particles, the number of clumps of particles and the number of particles per clump were all noted. The amount of IgM attached to virus particles was graded on a $\mathbf{0}$ to +++++ system. Samples were only scored as IgM-positive when the characteristic IgM-shaped antibody molecules were seen (Figure). Frequently there was insufficient IgM antibody to link the virus particles into clumps.

\section{Results}

BK-VIRUS SEROLOGY

The sera from 430 women in the survey ${ }^{20}$ were examined for the presence of BK-virus antibody, and $359(83.5 \%)$ found to have $\mathrm{HI}$ antibodies (titres $>$ 20). Twenty-seven $(6.3 \%)$ had high stable titres to BK-virus $(>640)$ throughout their pregnancy, 15 $(3.5 \%)$ had titres which showed a fourfold increase rising to 640 or greater during pregnancy, and $3(0.7 \%)$ had low titres which showed a fourfold increase in BK-virus antibody, but did not rise to 640 . Of the 45 women with high or rising titres to BK-virus, 28 $(62 \%)$ had BK-virus-specific IgM staining when tested by FA. At least one serum from each of these 28 women was fractionated on sucrose density gradients and $20(44 \%)$ of them had BK-virusspecific IgM, detected by $\mathrm{HI}$, in the IgM fractions. The sera from 30 women with no IgM specific FA staining were also fractionated but no BK-virusspecific IgM was detected in the appropriate fractions. In the sera from 20 women in which BK-virus IgM was detected by $\mathrm{HI}$, the titres were low (8-32) with the exception of one which had a high BK-virus-IgM titre $(>1024)$. BK-virus-specific IgM was confirmed 


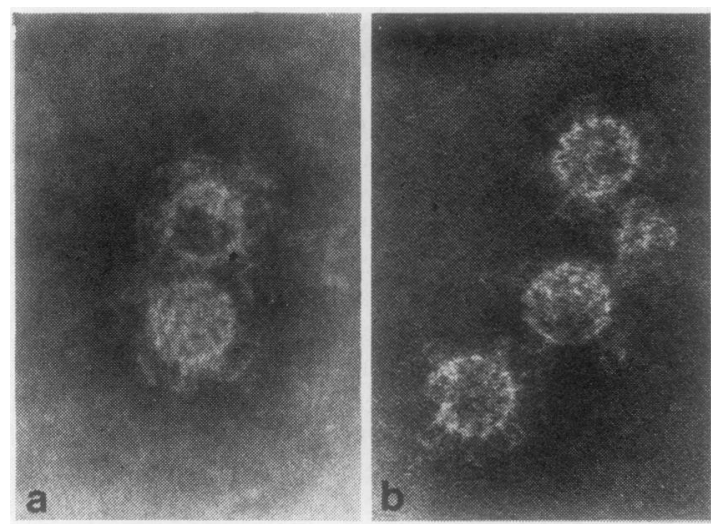

Immunoglobulin $M$ molecules attached to particles of $(a)$ $B K$-virus and (b) JC-virus. Negative stain $\times 200000$.

by IEM in only 10 of the 20 women (Table 1 ). These results suggest that either the FA test gives a large proportion of false-positive reactions or that it is more sensitive in detecting trace amounts of IgM. Sera from a control group of 28 pregnant women who had lower titres of total BK-virus antibody were also examined for BK-virus-specific IgM staining by FA. Only one of the 28 showed a slight fluorescence.

Table $1 B K$-virus IgM in 45 antenatal patients with high and/or rising antibody titres to BK-virus

\begin{tabular}{|c|c|c|c|c|c|}
\hline \multirow[t]{2}{*}{ HI antibodies } & \multirow{2}{*}{$\begin{array}{l}\text { Maximum } \\
\text { titre }\end{array}$} & \multirow[t]{2}{*}{ No } & \multicolumn{3}{|c|}{$B K$-virus IgM detected by } \\
\hline & & & $F A^{*}$ & $H I \dagger$ & $I E M \dagger$ \\
\hline $\begin{array}{l}\text { Rising titres } \times 4 \\
\text { Rising titres } \times 4 \\
\text { Stable titres }\end{array}$ & $\begin{array}{l}<640 \\
>640 \\
>640\end{array}$ & $\begin{array}{r}3 \\
15 \\
27\end{array}$ & $\begin{array}{r}1 \\
10 \\
17\end{array}$ & $\begin{array}{r}1 \\
10 \\
9\end{array}$ & $\begin{array}{l}\mathbf{0} \\
\mathbf{7} \\
\mathbf{3}\end{array}$ \\
\hline Total No & & 45 & $28(62 \%)$ & $20(44 \%)$ & $10(22 \%)$ \\
\hline
\end{tabular}

* FA was done on whole sera.

†HI and IEM were done on fractionated sera.

FA = immunofluorescence antibody test.

HI = haemagglutination inhibition (test).

IEM = immune electron microscopy.

No BK-virus-specific IgM could be detected by FA in the cord blood of any of the babies from the 45 women with high or rising titres to BK-virus. Table 1 compares the total BK-virus antibody status of the 45 women to the presence or absence of IgM in these women. Even by IEM, the least sensitive test, almost half $(47 \%)$ of those with high rising titres of BK-virus antibody had BK-virus-specific IgM.

Table 2 (patients 1-10) relates the appearance of BK-virus-specific IgM to the period of gestation in the 10 women who had IgM confirmed by IEM. In two of these women (patients 3 and 6), BK-virus IgM was detected in an early serum sample by FA but was not confirmed by $\mathrm{HI}$ and IEM after sucrose
Table 2 Occurrence of BK-virus IgM in 11 pregnant women

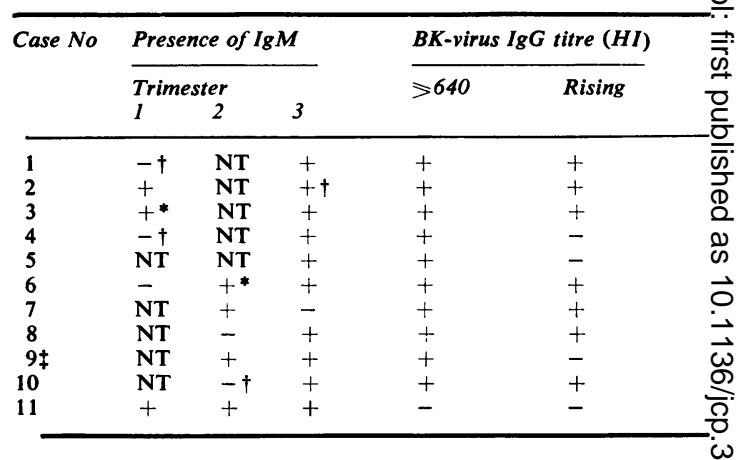

NT $=$ These sera were not tested because they were either not received or received in insufficient quantities.

*These sera were positive by the immunofluorescence antibody test foro BK-virus IgM but this was not confirmed by sucrose density gradient studies.

†These samples were tested by the immunofluorescence antibody tes? only.

$\ddagger$ This patient was excreting polyomavirus particles in her urine.

density gradient fractionation. However, in late serum specimens from these two women, BK-virus 00 specific IgM was detected by FA and in the fraction:ated sera it was confirmed both by HI and IEM? indicating that, indeed, the fluorescence test on wholes serum may be more sensitive for detecting trace्य amounts of IgM. As can be seen from Table $2 \frac{\mathrm{D}}{\mathrm{D}}$ BK-virus-specific IgM was present in all but one of the 10 women by the third trimester. In two of thes women (patients 2 and 3) BK-virus-specific IgM persisted for at least six months until delivery. The total BK-virus antibodies of one woman who did no? have persisting IgM (patient 7 ) rose from very low titres in the first trimester to high titres in the second and third. Patient 6 was the only one in whose serum a large amount of BK-virus IgM was found (HI titre in fractionated serum $>1024)$.

Only sera from 10 women which were positive by FA and which also had small amounts of BK-virus HI antibody in the IgM fractions were also positives in the IEM test (Table 1). This again is probably. explained by differences in sensitivity of the tests. An alternative explanation could be that even though the gel immunodiffusion test indicated that IgG and IgMR fractions were completely separated this test may nof be sensitive in detecting trace amounts of IgG in the IgM fractions which could give false-positives by $\mathrm{Hf}$ 은 Because of this, only fractions confirmed by IEM were considered positive for IgM.

Sera from all 430 women were examined for $\mathrm{H}_{5}^{\circ}$ antibodies to JC-virus and $208(48.4 \%)$ were found toD have titres of $>20$ to JC-virus. Of these, $70(16.3 \%$ 位 had high titres of $>640$ and $13(3 \%)$ had rising 
antibody titres. However, because an FA screening test was not available it was not practical to determine the JC-virus-specific IgM status of these women with high or rising titres to JC-virus.

BK-VIRUS AND JC-VIRUS SEROLOGY ON PATIENTS WITH INCLUSION-BEARING CELLS IN THE URINE

Forty of 1235 women from the previous study ${ }^{20}$ had evidence of polyomavirus infection during pregnancy, namely the presence of inclusion-bearing cells in the urinary sediment. Polyomavirus excretion was confirmed in 24 of these women by virus isolation or by electron microscopy or by both. The antibody status to BK- and JC-virus in this group of $\mathbf{4 0}$ had been previously reported. ${ }^{20}$ Table 3 compares the total BK-and JC-virus antibodies of this group to a group of the pregnant women in the same study chosen at random who showed no evidence of human polyomavirus infection during pregnancy. Higher numbers in the positive cytology group had antibody to JC-virus and fewer to BK-virus.

Table 3 BK-virus and JC-virus antibody titres in 40 pregnant women excreting inclusion-bearing cells compared with a control group of non-excretors

\begin{tabular}{|c|c|c|c|c|}
\hline \multirow{2}{*}{$\begin{array}{l}\text { Antibody } \\
\text { titres }(H I)\end{array}$} & \multicolumn{2}{|l|}{$B K$-virus } & \multicolumn{2}{|l|}{$J C$-virus } \\
\hline & $\begin{array}{l}\text { Positive } \\
\%(40)\end{array}$ & $\begin{array}{l}\text { Control } \\
\%(52)\end{array}$ & $\begin{array}{l}\text { Positive } \\
\%(40)\end{array}$ & $\begin{array}{l}\text { Control } \\
\%(50)\end{array}$ \\
\hline $\begin{array}{l}<20 \\
>20\end{array}$ & $\begin{array}{l}37 \cdot 5(15) \\
62 \cdot 5(25)\end{array}$ & $\begin{array}{l}11 \cdot 5(6) \\
88 \cdot 5(46)\end{array}$ & $\begin{array}{c}2 \cdot 5(1) \\
97 \cdot 5(39)\end{array}$ & $\begin{array}{l}56(28) \\
44(22)\end{array}$ \\
\hline
\end{tabular}

HI = haemagglutination inhibition.

The no. of pregnant women are given in parenthesis.

FA tests for BK-virus-specific IgM were performed on all the sera and at least one serum sample from each of the 40 women who had inclusion-bearing cells in their urine and 37 of the cord bloods of their infants were fractionated on sucrose density gradients and the IgG and IgM fractions investigated. In none of the cord bloods tested could BK-virus-specific IgM be demonstrated. In 36 of the cord bloods, no JCvirus-specific IgM was detected. However in one, JC-virus HI titres of 8-16 were found in four fractions two of which were in the IgM section of the gradient. This could not be confirmed by IEM and at present the nature of these antibodies is not known. The mother of this child presented in the second trimester and at this time, already had a high titre of JC-virus antibody which remained stable. JC-virusspecific IgM confirmed by IEM was found in all her serum samples, but no virus was isolated from her urine.

Sera from 30 of the women had only low HI titres to BK-virus $(₹ 40)$ and of these, only those from three women gave specific fluorescent staining for BK-virus IgM. This was confirmed on the fractionated serum by $\mathrm{HI}$ and IEM in only one of the three (patient 11, Table 2). The other 10 women had high HI titres to BK-virus $(>640)$ and nine of these gave specific fluorescent staining for BK-virus IgM. However, the presence of BK-virus-specific IgM was confirmed in only two cases by HI and IEM on the IgM fractions (patients 7 and 9 in Table 2). No BKvirus IgM was detected by sucrose density gradient studies, in women with negative FA results.

Because an FA screening test for JC-virus-specific IgM is not yet available, the sera were studied only by sucrose density gradient fractionation for the presence of JC-virus-specific IgM.

Thirty-nine of the $\mathbf{4 0}$ women had detectable $\mathrm{HI}$ antibody to JC-virus and 29 of these had high titres $(>640)$. In 11 of the 40 women, low HI antibody titres (2-8) were observed in the IgM fraction of at least one of their serum samples. In seven this was confirmed by IEM. This suggests that the HI test, again, may be slightly more sensitive than IEM. However, in one serum, IgM was detected by IEM and not by $\mathrm{HI}$, but in previous sera from this same individual JC-virus IgM was detected by both methods. All the women with detectable JC-virus IgM had high concentrations of JC-virus-specific IgG and from two of them a polyomavirus was isolated from the urine and identified as JC-virus. ${ }^{20}$

Table 4 relates the appearance of JC-virus-specific IgM (confirmed by IEM) to the period of gestation in the seven women. Six of these women had high stable titres of JC-virus antibody and the seventh had high rising titres. In most cases JC-virus-specific IgM persisted for several months and in one patient (patient 5), it was known to have persisted for at least seven months. Two patients had both BK- and JCvirus-specific IgM (patients 9 and 11 in Table 2 and 4 and 6 in Table 4). Both had small amounts of JC- and BK-virus-specific IgM confirmed by IEM but only one of these had high concentrations of BK-virusspecific IgG.

\section{Discussion}

In our study we found no evidence of primary polyomavirus infection occurring during pregnancy and thus the presence of specific IgM in maternal sera has been assumed to be due to reactivation of latent virus. The persistence of the IgM response in several of the pregnant women seems to indicate that once reactivated the BK-virus or JC-virus infection continues at least until delivery. Because we do not have a control group of normal non-pregnant women in the same age range, we do not know if reactivation 
Table 4 Occurrence of JC-virus-IgM in seven pregnant women excreting inclusion-bearing cells

\begin{tabular}{|c|c|c|c|c|c|}
\hline \multirow[t]{3}{*}{ Case No } & \multicolumn{3}{|c|}{ Presence of IgM } & \multicolumn{2}{|c|}{$J C$-virus antibody titre } \\
\hline & \multirow{2}{*}{\multicolumn{2}{|c|}{ Trimester }} & \multirow[b]{2}{*}{3} & \multirow[t]{2}{*}{$>640$} & \multirow[t]{2}{*}{ Rising } \\
\hline & & 2 & & & \\
\hline 1 & - & - & + & + & + \\
\hline $2^{*}$ & - & + & $+\dagger$ & + & - \\
\hline 3 & NT & + & + & + & - \\
\hline 4 & - & + & + & + & - \\
\hline 5 & + & + & + & + & - \\
\hline 6 & NT & + & + & + & - \\
\hline $7^{*}$ & - & + & + & + & - \\
\hline
\end{tabular}

* JC-virus isolated from urine of these patients.

†IgM detected by immune electron microscopy but not by haemagglutination inhibition.

NT $=$ Not tested.

of these human polyomaviruses occurs more often during pregnancy or whether the resulting infection persists longer in pregnant women than it would in the normal population. There have been variable reports on the occurrence of BK-virusspecific $\operatorname{IgM}$ in apparently healthy individuals. Jung et al. ${ }^{14}$ found no evidence of reactivation of BK-virus in a group of blood donors. However, Rziha et al. ${ }^{16}$ found BK-virus-specific IgM in $3 \%$ of (healthy) children. All these were under the age of 15 years and may have been experiencing a primary infection with BK-virus. Flower et al. ${ }^{15}$ also reported BK-virus IgM in several normal adults which in two instances persisted for more than a year. Chronic infection with polyomaviruses may therefore reflect an abnormal host response to the virus.

There have been previous investigations 102122 of BK-virus-specific IgM during pregnancy and in newborn babies. Taguchi and colleagues $(1975)^{21}$ were the first to report on the occurrence of BK-virusspecific IgM during pregnancy. They found it in four of the 80 Japanese women they tested and they also reported finding evidence of BK-virus-specific IgM in the cord blood of three babies. This was followed by a report from Germany by Rziha and colleagues ${ }^{10}$ who found BK-virus-specific IgM in $9.1 \%$ of the cord bloods they tested. Our present results and those from our previous study ${ }^{20}$ are in agreement with Borgatti and colleagues ${ }^{22}$ in Italy who found no evidence of BK-virus-specific IgM in the cord bloods of 253 infants. However, unlike Borgatti who found no BK-virus IgM in the mothers, we did find small amounts of BK-virus IgM in maternal sera. BK-virusspecific IgM was detected in three of the $\mathbf{4 0}$ mothers who had inclusion-bearing cells in their urine indicative of polyomavirus infection. Virus could not be isolated from the urine of any of these three women but in one the presence of a polyomavirus was confirmed by electron microscopy. The observation that one of these women had only very low titres of BK-virus-specific IgG throughout pregnancy may indicate that reactivation of BK-virus infection does not always produce increased levels of BK-virus antibody. However this same woman had very high $\underset{\overrightarrow{\mathrm{s}}}{\stackrel{\vec{m}}{.}}$ titres of JC-virus antibody so it is possible that the $\overrightarrow{0}$ BK-virus-IgM observed may be due to cross- $\frac{C}{0}$ reaction.

Very small amounts of BK-virus-specific IgM were $\overparen{\overparen{D}}$ detected in $10(22 \%)$ of 45 women who had rising or stable high antibody titres to BK-virus during ${ }^{\infty}$ pregnancy. A further 10 may also have had BK-virus $\vec{O}$ IgM, but this could not be confirmed by IEM. The $\overrightarrow{\vec{\omega}}$ most significant subgroup within this group consisted $\omega_{\sigma}$ of 15 women whose BK-virus $\mathrm{HI}$ antibody levels rose at least four-fold during pregnancy from titres of

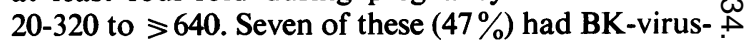
specific IgM confirmed by IEM. Overall, of the 430 patients studied at least $11(2.6 \%)$ had BK-virusspecific IgM and there may have been twice this number, a figure similar to that found by Taguchi and colleagues. ${ }^{21}$ In these 11 women there is no $\vec{c}$ evidence that BK-virus crossed the placenta and $\subsetneq$ infected the fetuses.

As yet there have been no reports on the occurrence $\vec{\oplus}$ of JC-virus-specific IgM. Although we were unable to $\stackrel{\infty}{-}$ screen the women in the survey by FA for JC-virusspecific IgM, the studies we did on the sera from the 40 cytologically-positive women and the cord bloods from their babies indicated that JC-virus tends to be reactivated more commonly during pregnancy than $\mathbb{D}$ BK-virus; JC-virus-specific IgM was detected and $\underset{\vec{T}}{\overrightarrow{2}}$ confirmed by IEM in seven $(17.5 \%)$ of the women. This finding can be correlated with those of the $\frac{3}{5}$ previous study ${ }^{20}$ on this group in which four of the six viruses isolated and identified were $\mathrm{JC}$-virus and only one was BK-virus.

In contrast to our findings with BK-virus, we have evidence that transplacental infection of JC-virus. may have occurred in one child whose mother hado evidence of a polyomavirus reactivation infection? during pregnancy. JC-virus-specific IgM was detected음 in small amounts in fractionated maternal sera and $>$ cord blood by HI, but could only be confirmed by을 IEM in the maternal sera. In the mother JC-virusspecific IgM was detected early in pregnancy and persisted until delivery. Except for this one case we ${ }_{0}^{N}$ have no other evidence that JC-virus can cross the ${ }_{\mathrm{E}}$ placenta during pregnancy and affect the fetus.

Production of specific IgM to BK-and JC-viruses, like virus excretion in these pregnant women, ${ }^{20}$ tended to persist to term. This probably reflects an $\stackrel{?}{+}$ altered state of immunity. They were not followed up 0 after delivery, so it is not known how long BK-virus- $-\vec{O}$ or JC-virus-specific IgM was produced in the postpartum period. The situation is similar to that禺 reported in renal transplant patients ${ }^{14}$ in whom 
BK-virus-specific IgM was found to persist over several months. Unlike renal transplant patients, however, the concentrations of IgM during pregnancy tend to be very low. Only one of the 16 pregnant women had high levels of polyomavirus-specific IgM and this was specific for BK-virus. During the first two trimesters of this woman's pregnancy BK-virusspecific IgM was detectable only by FA, but in the third trimester both BK-virus-specific IgG and IgM levels rose steeply (HI titres in fractionated sera $>$ 1024). No inclusion-bearing cells had been found in her urine and hence no attempt was made to isolate a polyomavirus. Like cytomegalovirus $(\mathrm{CMV})^{23}$ the polyomavirus IgM responses in pregnancy were thought to be due to reactivation of latent viruses because we found no evidence of primary infection. Schmitz and his colleagues ${ }^{23}$ also reported that CMV-specific IgM titres during pregnancy were low. However, they found that it persisted for periods of less than six months while we found that polyomavirus-specific IgM may last for longer periods, at least six to seven months in some cases.

Two of the women in our survey had IgM specific for both BK- and JC-viruses. One had high titres of total antibody to both JC- and BK-virus while the other had high titres to JC-virus only. Since no virus was isolated from either of these women, it is not known whether reactivation of both viruses occurred or if there is some cross-reaction between the two IgM species. Cross-reaction is more probable in serum from the woman who had high antibody titres to JC-virus only. This is similar to findings with two renal transplantation recipients in whom high titres of antibody to BK-virus and not JC-virus were observed, but in whom both BK-virus- and JC-virusspecific IgM were detected (unpublished results).

\section{References}

${ }^{1}$ Gardner SD, Field AM, Coleman DV, Hulme B. New human papovavirus (BK) isolated from urine after renal transplantation. Lancet $1971 ; \mathrm{i}: 1253-7$.

2 Padgett BL, Walker DL, ZuRhein GM, Eckroade RJ, Dessel RH. Cultivation of papova-like virus from human brain with progressive multifocal leucoencephalopathy. Lancet 1971 ; i:1257-60.

${ }^{3}$ Gardner SD. Prevalence in England of antibody to human polyomavirus (BK). Br Med J $1973 ; \mathrm{i}: 77-8$.

${ }^{4}$ Padgett BL, Walker DL. Prevalence of antibodies in human sera against JC virus, an isolate from a case of progressive multifocal leukoencepathy. J Infect Dis 1973; 127:467-70.

${ }^{5}$ Shah KV, Daniel RW, Warszawski RM. High prevalence of antibodies to BK virus, an SV40-related papovavirus, in residents of Maryland. J Infect Dis 1973;128:784-7.

- Mantyjarvi RA, Meurman OH, Vihma L, Berglund B. A human papovavirus (BK), biological properties and seroepidemiology. Ann Clin Res 1973;5:283-7.

7 Portolani M, Marzocchi A, Barbanti-Brodano G, LaPlaca $M$. Prevalence in Italy of antibodies to a new human papovavirus (BK virus). J Med Microbiol 1974;7:543-6.

${ }^{8}$ Brown P, Tsai T, Gajdusek DC. Seroepidemiology of human papovaviruses. Am J Epidemiol 1975;102:331-40.

9 Vander Noorda J, Wertheim-van Dillen P. Rise in antibodies to human papovavirus BK and clinical disease. Br Med J 1977;i:1471.

10 Rziha HJ, Bornkamm GW, Zur Hausen H. BK virus I: Seroepidemiologic studies and serological response to viral infection. Med Microbiol and Immunol 1978;165:7381.

${ }^{11}$ Coleman DV, Gardner SD, Fièld AM. Human polyomavirus infection in renal allograft recipients. $\mathrm{Br}$ Med J $1973 ;$ iii:371-5.

12 Takemoto KK, Rabson AS, Mullarkey MF, Blaese RM, Garon CF, Nelson D. Isolation of papovavirus from brain tumour and urine of a patient with Wiskott-Aldrich Syndrome. J Natl Cancer Inst 1974;53:1205-7.

${ }^{13}$ Reese IM, Reissig M, Daniel RW, Shah KV. Occurrence of BK-virus and BK-virus-specific antibodies in the urine of patients receiving chemotherapy for malignancy. Infect Immun 1975;11:1375-81.

14 Jung M, Krech U, Price PC, Pyndiah MN. Evidence of chronic persistent infections with polyomaviruses (BK type) in renal transplant recipients. Arch Virol 1975;47: 39-46.

${ }^{15}$ Flower AJE, Banatvala JE, Chrystie IL. BK antibody and virus specific IgM responses in renal transplant recipients, patients with malignant disease and healthy people. $\mathrm{Br}$ Med J 1977 ;ii:220-3.

${ }^{16}$ Rziha HJ, Belohradsky BH, Schneider U, et al. BK virus II. Serological studies in children with congenital disease and patients with malignant tumours and immunodeficiencies. Med Microbiol and Immunol 1978; $165: 83-92$.

17 McCance DJ, Mims CA. Transplacental transmission of polyoma virus in mice. Infect Immun 1977;18:196-202.

${ }^{18}$ Shah KV, Rangan SRS, Reissig M, Daniel RW, Beluhan FZ. Congenital transmission of a papovavirus of the stump-tailed macque. Science 1977;195:404-6.

${ }^{19}$ Gaugas JM, Curzen P. Polyamine interaction with pregnancy serum in suppression of lymphocyte transformation. Lancet 1978 ; : $18-20$.

${ }^{20}$ Colman DV, Wolfendale MR, Daniel RA, et al. A prospective study of human polyomavirus infection in pregnancy. J Infect Dis 1980;142:1-8.

21 Taguchi F, Nagaki D, Saito $M$, et al. Transplancental transmission of BK virus in humans. Jpn $J$ Microbiol 1975;19:395-8.

22 Borgatti M, Costanzo F, Portolani M, et al. Evidence for reactivation of persistent infection during pregnancy and lack of congenital transmission of BK virus, a human papovavirus. Microbiologica 1979;2:173-8.

${ }^{23}$ Schmitz H, Kampa D, Doerr HW, Luthardt T, Hillemanns HG, Wurteley A. IgM antibodies to cytomegalovirus during pregnancy. Arch Virol 1977;53:177-84.

Requests for reprints to: Dr PE Gibson, Virus Reference Laboratory, Central Public Health Laboratory, Colindale Avenue, London NW9 5HT, England. 